Article

\title{
Electrochemical Detection of Hydrazine Using Poly(dopamine)-Modified Electrodes
}

\author{
Ji Young Lee ${ }^{1}$, Truc Ly Nguyen ${ }^{2}$, Jun Hui Park ${ }^{3, *}$ and Byung-Kwon Kim ${ }^{2, *}$ \\ 1 Department of Chemistry, Korea Advanced Institute of Science and Technology, Daejeon 34141, Korea; \\ berry1504@kaist.ac.kr \\ 2 Department of Chemistry, Sookmyung Women's University, Seoul 04310, Korea; \\ trucly162@sookmyung.ac.kr \\ 3 Department of Chemistry Education and Institute of Fusion Science, Chonbuk National University, \\ Jeonju 54896, Korea \\ * Correspondence: echem@jbnu.ac.kr (J.H.P.); kimbk@sookmyung.ac.kr (B.-K.K.); \\ Tel.: +82-02-2077-7808 (B.-K.K.)
}

Academic Editor: W. Rudolf Seitz

Received: 5 March 2016; Accepted: 3 May 2016; Published: 5 May 2016

\begin{abstract}
We have developed a simple and selective method for the electrochemical detection of hydrazine (HZ) using poly(dopamine) (pDA)-modified indium tin oxide (ITO) electrodes. Modification with pDA was easily achieved by submerging the ITO electrode in a DA solution for $30 \mathrm{~min}$. The electrocatalytic oxidation of $\mathrm{HZ}$ on the pDA-modified ITO electrode was measured by cyclic voltammetry. In buffer solution, the concentration range for linear $\mathrm{HZ}$ detection was $100 \mu \mathrm{M}-10 \mathrm{mM}$, and the detection limit was $1 \mu \mathrm{M}$. The proposed method was finally used to determine $\mathrm{HZ}$ in tap water to simulate the analysis of real samples. This method showed good recovery $(94 \%-115 \%)$ and was not affected by the other species present in the tap water samples.
\end{abstract}

Keywords: hydrazine; detection; indium tin oxide electrode; dopamine; poly(dopamine) film; cyclic voltammetry

\section{Introduction}

Hydrazine $\left(\mathrm{HZ}, \mathrm{N}_{2} \mathrm{H}_{4}\right)$ is an inorganic compound that exists as a volatile and flammable colorless liquid. HZ and its derivatives are mainly used in fuel-cell technology [1] and as propellants in rocket fuel, pesticides for agriculture, intermediates in photoprinting and pharmaceuticals, and deoxidizers in boilers. HZ is considered hazardous and is classified as a carcinogen by the US Environmental Protection Agency (EPA) [2] because it can cause chromosome aberrations and negatively affect the lungs, liver, spleen, thyroid gland, and central nervous system. Therefore, methods for the detection and monitoring systems for $\mathrm{HZ}$ should be developed to meet the demands of both industries and environmental groups. To date, various analytical methods such as titrimetry [3], chromatography [4], spectrophotometry [5], flow injection analysis with chemiluminescence [6], potentiometry [7], and amperometry [8-11] have been used for HZ detection. Among these techniques, electrochemical methods have advantages of simplicity, high sensitivity, rapid response, and low cost. To detect HZ using electrochemical methods, electrodes should be modified using special materials with electrocatalytic activities for the electrochemical oxidation of $\mathrm{HZ}$ to overcome the limitations associated with the high overpotential and sluggish kinetics of $\mathrm{HZ}$ in electrochemical reactions [12]. To achieve this, many studies have suggested the modification of electrodes by employing nanoparticles (e.g., $\mathrm{Au}, \mathrm{Ti}, \mathrm{Pd}, \mathrm{ZnO}, \mathrm{Co}, \mathrm{Sn}, \mathrm{ZrO}_{2}, \mathrm{Bi}$, and $\mathrm{Ce}$ ) [13-21], CoPC nanoparticles [22], manganese hexacyanoferrate [9], $\mathrm{CoOOH}$ nanosheets [12], zinc oxide nanowires [23], 4-pyridyl hydroquinone [24], biomolecules [25], and branched hierarchical $\mathrm{ZnO}$ nanorod arrays [26]. However, in many cases, 
creating these materials and using them to modify the electrode requires several preparation steps, which not only increases the cost of implementing the technique but also decreases its reproducibility. Therefore, simple and reproducible modification methods are urgently needed. To meet this requirement, in this study we adopted poly(dopamine) (pDA) to modify electrodes to detect HZ. We used pDA as a modifier or an electrocatalyst [19,27-31], because pDA can be simply and quickly formed on many substrates in basic solutions [32-35].

Indium tin oxide (ITO) electrodes are mainly used in display and solar cell applications because of their good electrical conductivity, optical transparency, and low cost. These electrodes are particularly applicable to electrochemical sensors because of their low background current and high reproducibility [36,37]. Another characteristic property of ITO electrodes is that they have lower catalytic activity than other metal (e.g., $\mathrm{Pt}, \mathrm{Au}$, and $\mathrm{Pd}$ ) electrodes, which can suppress interfering electrochemical reactions during measurements. Although the low catalytic activity of ITO electrodes can also decrease the target (e.g., HZ) current signal, this problem can be resolved by modifying the electrodes with specific materials.

Herein, we propose a pDA-modified ITO electrode for sensitive detection of HZ in solution. Because the formation of pDA films from DA solution is spontaneous and rapid, pDA-modified ITO electrodes were very easily obtained by submerging the electrodes in a DA solution for $30 \mathrm{~min}[27,33,38]$. It is already known that DA polymerizes spontaneously to pDA in basic solution; in this process, DA is first oxidized to dopaminequinone, followed by intramolecular cyclization and rearrangement. Next, the product, leukodopaminechrome, is oxidized to dopaminechrome. Finally, dopaminechrome polymerizes to $\mathrm{pDA}$ on an ITO electrode. We used the resulting $\mathrm{pDA}$-ITO electrode to detect HZ. As shown in Figure 1, the electrochemical reaction occurred on the pDA-ITO electrode when an appropriate potential was applied. In this process, pDA on the ITO electrode is first oxidized to poly(dopamine-o-quinone) (pDQ), generating an anodic current, and it is then reduced back to $\mathrm{pDA}$ by HZ, which is a strong reducing agent. Because of this redox cycling reaction, very high anodic currents can be obtained.
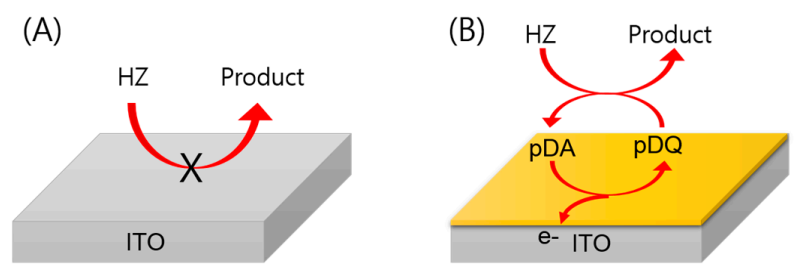

Figure 1. (A) Electrochemical oxidation of HZ rarely occurs on a bare ITO electrode; (B) HZ can be readily detected because of the electrochemical-chemical (EC) reaction on the pDA-ITO electrode.

\section{Materials and Methods}

\subsection{Chemicals and Instruments}

Dopamine hydrochloride, $\mathrm{HZ}, \mathrm{KCl}, \mathrm{Na}_{3} \mathrm{PO}_{4}, \mathrm{CaCO}_{3}, \mathrm{ZnCl}_{2}, \mathrm{MgSO}_{4}, \mathrm{MnCl}_{2}, \mathrm{FeCl}_{2}, \mathrm{CoCl}_{2}$, and Tris were acquired from Sigma-Aldrich (Yongin, Korea). Unless otherwise indicated, all reagents were used as received. Tris buffer was prepared using $0.05 \mathrm{M}$ Tris, $0.138 \mathrm{M} \mathrm{NaCl}$, and $0.0027 \mathrm{M} \mathrm{KCl}$. All aqueous solutions were made with ultrapure water $(>18 \mathrm{M} \Omega \cdot \mathrm{cm}$, Millipore, Darmstadt, Germany). ITO electrodes $(30 \Omega)$ were purchased from Samsung Corning (Daegu, Korea). Electrochemical measurements were performed using a CHI617B device (CH Instruments, Austin, TX, USA).

\subsection{Electrochemical Measurement}

A standard three-electrode cell with an ITO working electrode, a Au wire counter electrode, and a $\mathrm{Ag} / \mathrm{AgCl}$ reference electrode $(3 \mathrm{M} \mathrm{KCl})$ was used. The area of the ITO working electrode was $0.28 \mathrm{~cm}^{2}$. The ITO working electrodes were sequentially washed in acetone, ethanol, and ultrapure 
water with ultrasonication for $15 \mathrm{~min}$. The pDA-ITO working electrodes were obtained by submerging the cleaned ITO electrodes in Tris buffer containing $1 \mathrm{mM}$ DA for $30 \mathrm{~min}$. Subsequently, the pDA-ITO electrodes were washed with distilled water. All HZ-detection experiments were conducted in Tris buffer using pDA-ITO electrodes. All experiments were carried out at room temperature. Air-saturated solutions were used without any further preparation step (e.g., Ar bubbling).

\section{Results and Discussion}

\subsection{Electrochemical Detection of $H Z$}

The electrochemical oxidation properties of $\mathrm{HZ}$ were examined on a bare ITO electrode using commercially available Tris buffer ( $\mathrm{pH} 8$ ) (Figure 2). In the absence of $\mathrm{HZ}$, only the capacitive current of the bare ITO electrode was measured (Figure 2A). In the presence of $1 \mathrm{mM} \cdot \mathrm{HZ}$, a sluggish oxidation peak was observed because of the slow electron transfer between $\mathrm{HZ}$ and the bare ITO electrode (Figure 2B). This slow electron transfer leads to a low anodic current and prevents sensitive detection. Thus, for HZ sensing applications, the HZ oxidation current must be increased.

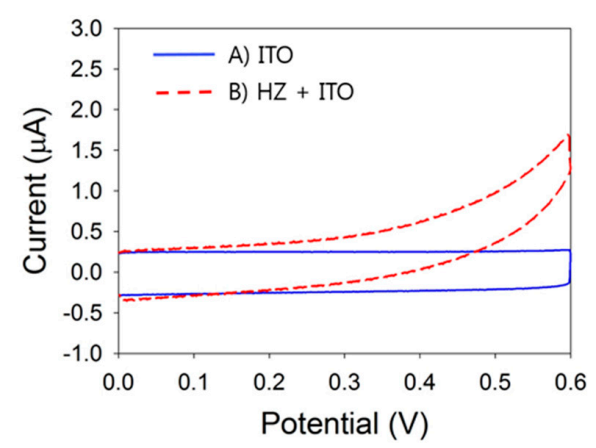

Figure 2. Cyclic voltammograms of (A) Tris buffer ( $\mathrm{pH}$ 8) and (B) $1 \mathrm{mM} \cdot \mathrm{HZ}$ in Tris buffer (pH 8) using an ITO electrode at a scan rate $50 \mathrm{mV} / \mathrm{s}$.

Spontaneous formation of a pDA film was achieved on a bare ITO electrode by simply immersing the electrode in Tris buffer containing $1 \mathrm{mM}$ DA for $30 \mathrm{~min}$. The resulting pDA film can be easily oxidized at the ITO electrode [34]. Previously, we suggested a DA-detection method using pDA films on ITO electrodes in the presence of $\mathrm{HZ}$, wherein the oxidation current of pDA increased proportionally to the concentration of DA [35]. By inverting the concept underlying the previously described method, pDA films can be used as electrocatalytic mediators for sensitive detection of $\mathrm{HZ}$ oxidation. For this purpose, $\mathrm{HZ}$ oxidation was performed on pDA film-modified ITO electrodes in Tris buffer containing $1 \mathrm{mM} \cdot \mathrm{HZ}$. Unlike the case with the bare ITO electrode, we observed a large peak-shaped HZ oxidation current of approximately $60 \mu \mathrm{A}$ at roughly $0.3 \mathrm{~V}$ in the modified electrode (Figure 3).

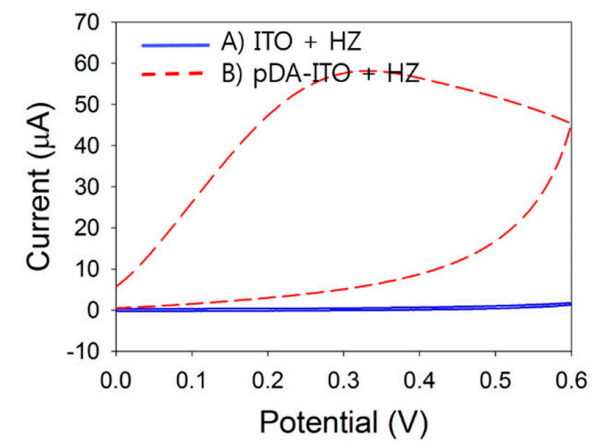

Figure 3. Cyclic voltammograms of $1 \mathrm{mM} \cdot \mathrm{HZ}$ in Tris buffer with (A) an ITO electrode and (B) a pDA-ITO electrode at a scan rate $50 \mathrm{mV} / \mathrm{s}$. 
This $60 \mu \mathrm{A}$ current represents an increase of nearly 40 -fold compared with that with the bare ITO electrode $(c a .0 .15 \mu \mathrm{A})$. These results indicate that $\mathrm{HZ}$ oxidation by the pDA film could be applied for sensitive detection of HZ. Two reactions occurred simultaneously at the pDA-ITO electrode: the first is electrochemical oxidation of $\mathrm{pDA}$ to $\mathrm{pDQ}$ on the ITO electrode surface, and the second is $\mathrm{pDQ}$ reduction by $\mathrm{HZ}$ oxidation. We believe that the high anodic current shown in Figure 3 (red line) is governed by the diffusion process of $\mathrm{HZ}$ in solution. This is confirmed by the plot of the anodic peak current versus square root of the scan rate (Figure 4). As shown in Figure 4B, the anodic peak currents showed good linearity with the square root of scan rate. Therefore, it is clear that the anodic current is certainly generated by the diffusion process of $\mathrm{HZ}$ in solution at the pDA-ITO electrode.
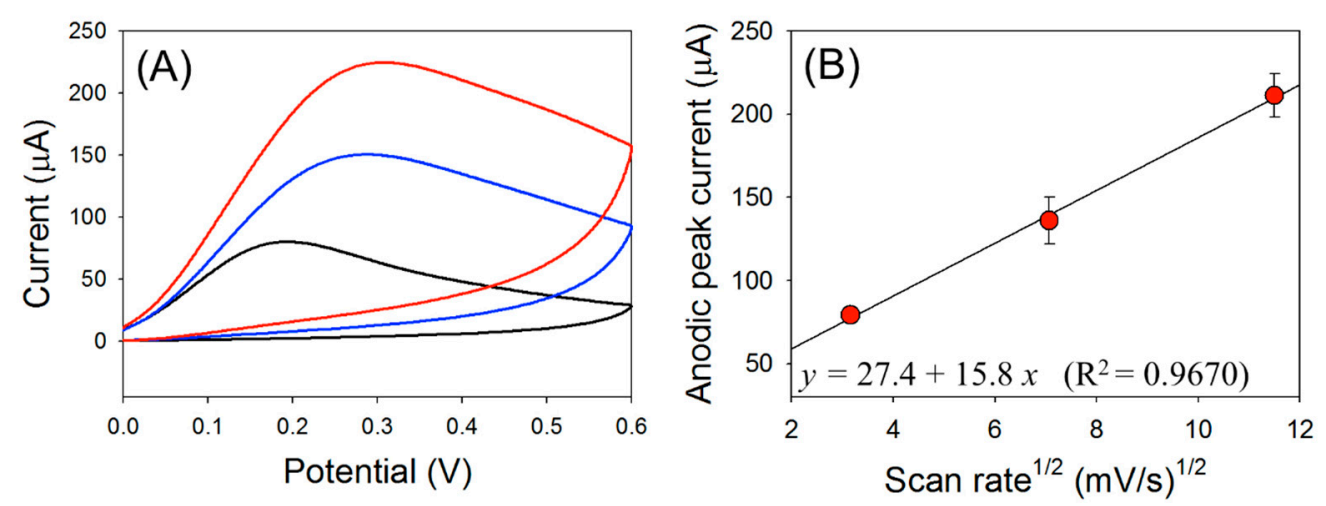

Figure 4. (A) Cyclic voltammograms of $10 \mathrm{mM} \cdot \mathrm{HZ}$ in Tris buffer with pDA-ITO electrodes at a scan rate of $10 \mathrm{mV} / \mathrm{s}$ (black line), $50 \mathrm{mV} / \mathrm{s}$ (blue line), and $100 \mathrm{mV} / \mathrm{s}$ (red line); (B) Dependence of the anodic peak current on the square root of the scan rate.

\subsection{Optimization of the Experimental Conditions for HZ Detection}

To maximize the $\mathrm{HZ}$ oxidation current, we varied the amount of DA and the $\mathrm{pH}$ of the Tris buffer containing HZ. First, the oxidation currents in $1 \mathrm{mM} \cdot \mathrm{HZ}$ were measured with different amounts of DA on the ITO electrodes. The amount of DA can be controlled by varying the duration for which ITO electrodes are submerged in Tris buffer containing $1 \mathrm{mM}$ DA. Figure 5 shows that the HZ oxidation current linearly increases up to a submersion time of $20 \mathrm{~min}$ and reaches saturation at $30 \mathrm{~min}$.

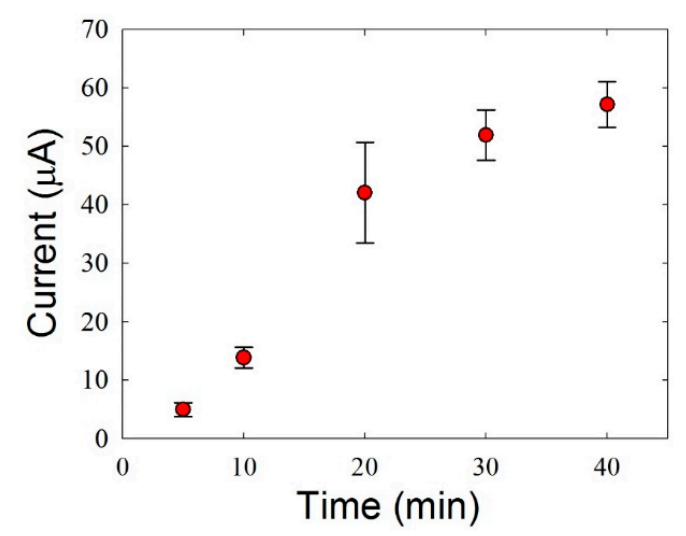

Figure 5. Oxidation currents according to the duration of the submersion of ITO electrodes in $1 \mathrm{mM}$ DA. The error bars indicate the standard deviations of at least three measurements.

Based on this result, we selected 30 min of submersion as the optimal value. Next, the $\mathrm{pH}$ of the Tris buffer used for the electrochemical measurement was investigated because the oxidation current of pDA to pDQ can be altered based on the pKa value (8.8) of DA [39]. ITO electrodes submerged in $1 \mathrm{mM}$ 
DA for $30 \mathrm{~min}$ were tested in Tris buffer containing $1 \mathrm{mM} \cdot \mathrm{HZ}$ with various $\mathrm{pH}$ values. The tested $\mathrm{pH}$ values ranged from 8 to 10, and the highest oxidation current was observed at pH 9 (Figure 6). Therefore, Tris buffer with $\mathrm{pH} 9$ was chosen as the optimal test solution for HZ detection.

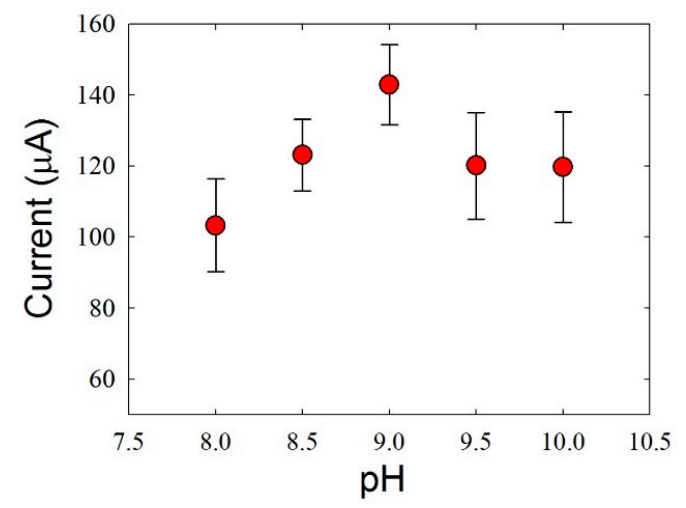

Figure 6. Oxidation currents based on the $\mathrm{pH}$ of the Tris buffer. The ITO electrodes were submerged in $1 \mathrm{mM}$ DA for $30 \mathrm{~min}$ and then measured in $1 \mathrm{mM}$. HZ. The error bars indicate the standard deviations of at least three measurements.

The subsequent HZ-detection experiments were performed under the optimal conditions of 30 min of ITO electrode submersion in DA solution and measurement in Tris buffer with pH 9.

\subsection{HZ-Sensing Performances}

Cyclic voltammetry was conducted to determine the concentrations of $\mathrm{HZ}$ on the pDA film-modified ITO electrodes at a scan rate of $50 \mathrm{mV} / \mathrm{s}$. The oxidation peak currents at approximately $0.3 \mathrm{~V}$ were linearly proportional to the $\mathrm{HZ}$ concentration in the range of $100 \mu \mathrm{M}-10 \mathrm{mM}$ (Figure $7 \mathrm{~A}$ ).
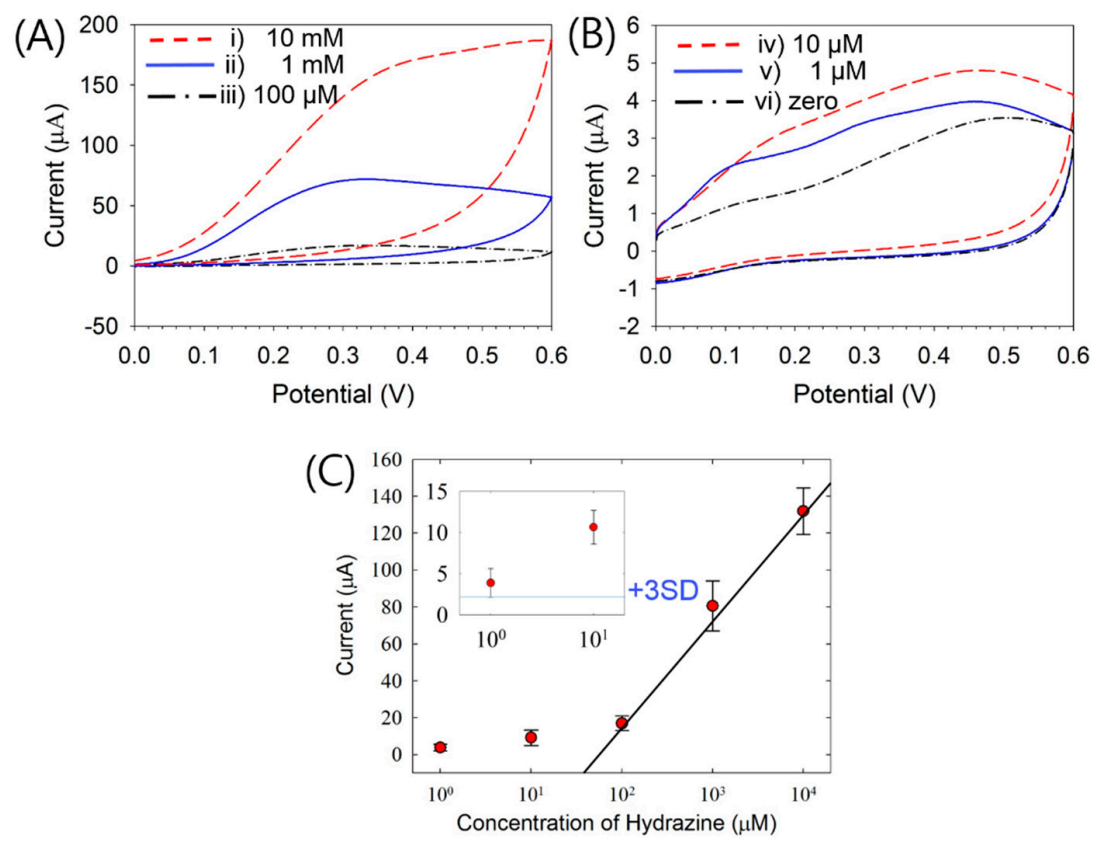

Figure 7. (A,B) Cyclic voltammograms for various concentrations of $\mathrm{HZ}$ in Tris buffer ( $\mathrm{pH} 9$ ) using pDA-ITO electrodes at a scan rate of $50 \mathrm{mV} / \mathrm{s}$ : (A) (i) $10 \mathrm{mM}$, (ii) $1 \mathrm{mM}$, (iii) $100 \mu \mathrm{M}$, (B) (iv) $10 \mu \mathrm{M}$, (v) $1 \mu \mathrm{M}$, and vi) zero. (C) Calibration plot of anodic currents at $0.3 \mathrm{~V}$. The 3SD line represents the mean current plus three times the standard deviation at $0.3 \mathrm{~V}$ for $0 \mu \mathrm{M} \mathrm{HZ}$. The error bars indicate the standard deviations of six measurements. 
The linear relationship between the oxidation currents and $\mathrm{HZ}$ concentrations in this range can be described by the following equation (Figure 7C):

$$
y=60.5 \log (x)( \pm 8.37 \%)-101( \pm 14.9 \%) ;\left(R^{2}=0.9070,10^{2} \leqslant x \leqslant 10^{4}\right)
$$

Unlike the case of high concentrations $(\geqslant 100 \mu \mathrm{M})$, another oxidation peak with an ambiguous shape appeared at approximately $0.1 \mathrm{~V}$ at low concentrations $(\leqslant 10 \mu \mathrm{M})$ (Figure $7 \mathrm{~B})$. We believe that this phenomenon occurred owing to the oxidation of the pDA film when the HZ concentration was lower than the DA concentration [30]. Therefore, we chose to measure the HZ concentration using the oxidation peak current at $0.3 \mathrm{~V}$.

Although the oxidation peak currents increased with the HZ concentration (Figure 7), Figure 7C shows that this relationship was not linear when the concentration was lower than $10 \mu \mathrm{M}$. Indeed, the oxidation current of $1 \mu \mathrm{M} \mathrm{HZ}$ shown in the inset of Figure 7C is higher than the 3SD line, indicating that the limit of detection of this method is $1 \mu \mathrm{M} \mathrm{HZ}$. Therefore, the linear concentration range for $\mathrm{HZ}$ detection is $100 \mu \mathrm{M}-10 \mathrm{mM}$, and the detection limit is $1 \mu \mathrm{M}$. These values are comparable to those of other previously reported methods using, for example, nanoparticles [12,40], oxide materials [25,41], and polymers [42] (Table 1).

Table 1. Comparison of surface-modified electrodes for HZ detection.

\begin{tabular}{|c|c|c|c|c|}
\hline Type of Electrode & $\begin{array}{c}\text { Detection } \\
\text { Limit }(\mu \mathrm{M})\end{array}$ & $\begin{array}{c}\text { Linear } \\
\text { Range }(\mu \mathrm{M})\end{array}$ & Sample Condition & Reference \\
\hline a MnHCF-modified graphite-wax composite & 6.65 & $33.3-8180$ & $\mathrm{Fe}(\mathrm{CN})_{6}{ }^{4-} / \mathrm{Fe}(\mathrm{CN})_{6}{ }^{3}$ & [9] \\
\hline $\mathrm{CoOOH}$ nanosheets & 20 & $0-1000$ & $0.1 \mathrm{M} \mathrm{NaOH}$ & [12] \\
\hline${ }^{\mathrm{b}} \mathrm{CoPc}-(\mathrm{CoTPP})_{4} /{ }^{\mathrm{c}} \mathrm{GCE}$ & 230 & _ & $0.2 \mathrm{M} \mathrm{NaOH}$ & [22] \\
\hline${ }^{\mathrm{d}} \mathrm{Hb} / \mathrm{ZnO} /{ }^{\mathrm{e}} \mathrm{CNF} / \mathrm{GCE}$ & 6.60 & $19.8-1710$ & $0.1 \mathrm{M}^{\mathrm{f}} \mathrm{PBS}(\mathrm{pH} 7)$ & [25] \\
\hline $\mathrm{SnO}_{2}$ /guar-gum hybrid nanocomposite & 2760 & $2000-22,000$ & $\mathrm{Fe}(\mathrm{CN})_{6}{ }^{4-} / \mathrm{Fe}(\mathrm{CN})_{6}{ }^{3}$ & [40] \\
\hline Zinc oxide nanorods & $\sim 515.7$ & $0.3-300$ & $0.1 \mathrm{M}$ PBS & [41] \\
\hline Overoxidized polypyrrole & 3.7 & $1.3-2000$ & 0.1 M ammonium buffer ( $\mathrm{pH} 9$ ) & [42] \\
\hline ZnO-g RGO & 0.8 & $1-33,500$ & $0.1 \mathrm{M} \mathrm{NaOH}$ & [43] \\
\hline $\mathrm{ZnO}$ nanoparticles & 0.35 & $0.5-5000$ & 0.01 M PBS (pH 7.5) & [44] \\
\hline $\mathrm{ZnO}$ nanoparticles II & 0.147 & - & 0.01 M PBS (pH 7.0) & [45] \\
\hline $\mathrm{ZnO}$ nanofilm & 0.5 & $0.5-\overline{14}, 200$ & $0.1 \mathrm{M} \mathrm{NaOH}$ & [46] \\
\hline $\mathrm{Mn}_{2} \mathrm{O}_{3}$ nanorods & 1.1 & $2-1300$ & 0.01 M PBS (pH 7.0) & [47] \\
\hline${ }^{\text {h }}$ PdNPs $/{ }^{\mathrm{I}}$ PTAA/GCE & 0.00267 & $0.008-10$ & 0.01 M PBS (pH 7.0) & [48] \\
\hline j PEDOT:k PSS/Pd & 0.12 & $0.4-100$ & 0.2 M PBS (pH 6.86) & [49] \\
\hline Pd-l'GG-g-PAM-silica & 4.1 & $50-180,000$ & PBS (pH 7.0) & [50] \\
\hline${ }^{\mathrm{m}} \mathrm{AuNPs} /{ }^{\mathrm{n}}$ poly $(\mathrm{BCP}) /{ }^{\circ} \mathrm{CNT} / \mathrm{GCE}$ & 0.1 & $0.5-1000$ & 0.1 M PBS (pH 10.0) & [51] \\
\hline 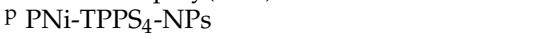 & 0.11 & _ & $0.1 \mathrm{M} \mathrm{NaOH}$ & [52] \\
\hline${ }^{\mathrm{q}}$ nano-CoTAPC SPEs & 30 & $10-100$ & PBS (pH 7.4) & [53] \\
\hline PdNPs $/$ RGO $^{\mathrm{r}}$ RDEs & 0.007 & $0.1-1000$ & 0.2 M PBS (pH 7.4) & [18] \\
\hline $\mathrm{pDA} / \mathrm{ITO}$ & 1 & $100-10,000$ & $0.05 \mathrm{M}$ Tris buffer & This work \\
\hline \multicolumn{5}{|c|}{ 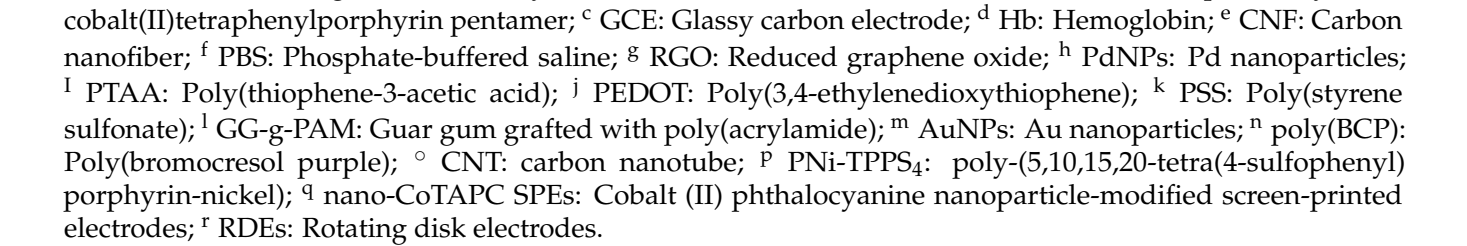 } \\
\hline
\end{tabular}

\subsection{Influence of Interference Molecules for Detecting HZ and the Stability of pDA-ITO Electrodes}

To apply this method to real samples, the pDA-ITO electrodes were used to detect various $\mathrm{HZ}$ concentrations in tap water solution with additional ions (containing $50 \mathrm{mM}$ Tris, $300 \mu \mathrm{M} \mathrm{Na}^{+}$, $100 \mu \mathrm{M} \mathrm{Ca}^{2+}, 100 \mu \mathrm{M} \mathrm{Zn}^{2+}, 100 \mu \mathrm{M} \mathrm{Mg}^{2+}, 100 \mu \mathrm{M} \mathrm{Co}^{2+}, 100 \mu \mathrm{M} \mathrm{Fe}^{2+}, 600 \mu \mathrm{M} \mathrm{Cl}^{-}, 100 \mu \mathrm{M} \mathrm{PO}_{4}{ }^{3-}$, $100 \mu \mathrm{M} \mathrm{SO}_{4}{ }^{2-}$, and $100 \mu \mathrm{M} \mathrm{CO}_{3}{ }^{2-}$ ) (see the Supporting Information, Figure S1). As shown in Table 2, eight samples of tap water, four containing $100 \mu \mathrm{M}$ and the other four containing $1000 \mu \mathrm{M} \mathrm{HZ}$, could be detected using the pDA-modified ITO electrode with good recovery $(94 \%-115 \%)$. 
Table 2. Determination of $\mathrm{HZ}$ in tap water containing ions.

\begin{tabular}{ccccc}
\hline Added $(\mu \mathbf{M})$ & Sample & Current at $\mathbf{0 . 3} \mathbf{~ V ~}(\boldsymbol{\mu A})$ & Found $(\mu \mathbf{M})$ & Recovery $(\%)^{\mathbf{a}}$ \\
\hline \multirow{3}{*}{100} & 1 & 21.5 & 105 & 105 \\
& 2 & 20.1 & 100 & 100 \\
& 3 & 23.2 & 112 & 112 \\
4 & 21.1 & 104 & 104 \\
\hline \multirow{3}{*}{1000} & 1 & 78.9 & 940 & 94 \\
& 2 & 81.3 & 1030 & 103 \\
& 3 & 79.6 & 966 & 96.6 \\
\hline
\end{tabular}

All solutions comprise tap water containing ions $\left(50 \mathrm{mM}\right.$ Tris, $300 \mu \mathrm{M} \mathrm{Na}^{+}, 100 \mu \mathrm{M} \mathrm{Ca}^{2+}, 100 \mu \mathrm{M} \mathrm{Zn}{ }^{2+}$, $100 \mu \mathrm{M} \mathrm{Mg}^{2+}, 100 \mu \mathrm{M} \mathrm{Co}^{2+}, 100 \mu \mathrm{M} \mathrm{Fe}^{2+}, 600 \mu \mathrm{M} \mathrm{Cl}^{-}, 100 \mu \mathrm{M} \mathrm{PO}_{4}{ }^{3-}, 100 \mu \mathrm{M} \mathrm{SO}_{4}{ }^{2-}$, and $\left.100 \mu \mathrm{M} \mathrm{CO}_{3}{ }^{2-}\right)$;

a Recovery $(\%)=\left(C_{\text {Found }} / C_{\text {Added }}\right) \times 100 \%$.

Stabilities of pDA-ITO electrodes were measured with respect to time in a tap water solution containing additional ions (containing $50 \mathrm{mM}$ Tris, $300 \mu \mathrm{M} \mathrm{Na}^{+}, 100 \mu \mathrm{M} \mathrm{Ca}^{2+}, 100 \mu \mathrm{M} \mathrm{Zn}^{2+}, 100 \mu \mathrm{M}$ $\mathrm{Mg}^{2+}, 100 \mu \mathrm{M} \mathrm{Co}^{2+}, 100 \mu \mathrm{M} \mathrm{Fe}^{2+}, 600 \mu \mathrm{M} \mathrm{Cl}^{-}, 100 \mu \mathrm{M} \mathrm{PO}_{4}{ }^{3-}, 100 \mu \mathrm{M} \mathrm{SO}_{4}{ }^{2-}$, and $100 \mu \mathrm{M} \mathrm{CO}_{3}{ }^{2-}$ ). Sixty-four electrodes were prepared on the same day, and four electrodes were used to measure the same amount of $\mathrm{HZ}$ each day (tap water solution with additional ions). The prepared electrodes were stored in a refrigerator at $4{ }^{\circ} \mathrm{C}$. As shown in Figure 8, the normalized currents indicated that the detection currents decrease with time. When we used pDA-ITO electrodes 1 day later, $93.9 \%( \pm 7.96 \%)$ and $90.1 \%( \pm 10.5 \%)$ currents were observed when detection experiments were carried out at $1 \mathrm{mM}$ and $0.1 \mathrm{mM} \cdot \mathrm{HZ}$, respectively. After 3 days, the normalized currents decreased to $69.5 \%( \pm 4.34 \%)$ and $67.6 \%( \pm 1.2 \%)$, respectively, for $1 \mathrm{mM}$ and $0.1 \mathrm{mM} \cdot \mathrm{HZ}$. We observed similar decreasing trends in both $1 \mathrm{mM}$ and $0.1 \mathrm{mM} \cdot \mathrm{HZ}$ detection experiments. This result means that the pDA-ITO electrodes are not suitable for long-term usage. However, more experiments are needed to extend the stability of pDA-ITO electrodes.

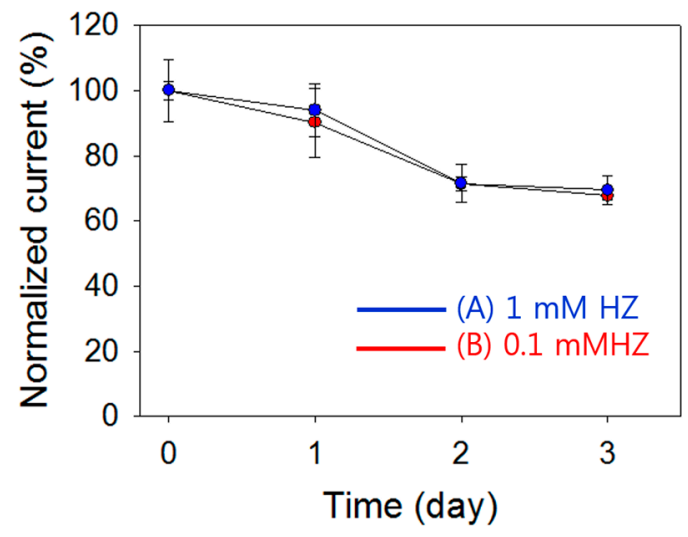

Figure 8. Normalized current (at $0.3 \mathrm{~V}$ ) for $\mathrm{HZ}$ detection according to the time (day). (A) $1 \mathrm{mM} \cdot \mathrm{HZ}$ and (B) $0.1 \mathrm{mM}$. HZ were detected. The error bars indicate the standard deviations of 4 measurements.

\section{Conclusions}

We have developed a simple and fast EC-based HZ-detection method using pDA film-modified ITO electrodes. The modification of ITO electrodes with pDA films was easily achieved by submerging the electrodes in a DA solution for $30 \mathrm{~min}$. The pDA film acts as a mediator for the EC reaction and shows good performance in the detection of $\mathrm{HZ}$. This $\mathrm{HZ}$ detection method has a linear dynamic range of $100 \mu \mathrm{M}-10 \mathrm{mM}$ and has a detection limit of $1 \mu \mathrm{M}$. When it is used to analyze tap water containing various concentrations of $\mathrm{HZ}$, it showed good recovery and was not affected by other ionic species present in the samples. 
Supplementary Materials: The following are available online at http:/ /www.mdpi.com/1424-8220/16/5/647/s1, Figure S1. The detail information of cyclic voltammograms in tap water solution with additional ions.

Acknowledgments: This work was supported by the Basic Science Research Program through the National Research Foundation of Korea (NRF) funded by the Ministry of Science, ICT and Future Planning (NRF-2013R1A1A1059719 and NRF-2015R1C1A1A01055250) and the Sookmyung Women's University Research Grants (1-1603-2005).

Author Contributions: J.Y.L. and T.L.N. contributed equally to this work. All authors read and approved the final manuscript. B.-K.K. designed the experiments; J.Y.L. and T.L.N. performed the experiments; J.Y.L., B.-K.K. and J.H.P. wrote, approved and revised the paper.

Conflicts of Interest: The authors declare no conflict of interest.

\section{Abbreviations}

The following abbreviations are used in this manuscript:

$\begin{array}{ll}\text { EPA } & \text { Environmental Protection Agency } \\ \text { HZ } & \text { Hydrazine } \\ \text { ITO } & \text { Indium tin oxide } \\ \text { pDA } & \text { Poly(dopamine) } \\ \text { pDQ } & \text { Poly(dopamine-o-quinone) }\end{array}$

\section{References}

1. Durga, S.; Ponmani, K.; Kiruthika, S.; Muthukumaran, B. Electrochemical oxidation of hydrazine in membraneless fuel cells. J. Electrochem. Sci. Technol. 2014, 5, 73-81. [CrossRef]

2. United States Environmental Protection Agency. Technology Transfer Network-Air Toxics Web Site. Available online: http://www.epa.gov/ttn/atw/hlthef/hydrazin.html (accessed on 2 March 2008).

3. Budkuley, J.S. Determination of hydrazine and sulfite in the presence of one another. Microchim. Acta 1992, 108, 103-105. [CrossRef]

4. Mori, M.; Tanaka, K.; Xu, Q.; Ikedo, M.; Taoda, H.; Hu, W.Z. Highly sensitive determination of hydrazine ion by ion-exclusion chromatography with ion-exchange enhancement of conductivity detection. J. Chromatogr. A 2004, 1039, 135-139. [CrossRef] [PubMed]

5. Arulraj, A.D.; Vijayan, M.; Vasantha, V.S. Spectrophotometric determination of pico-molar level of hydrazine by using Alizarin red in water and urine samples. Spectrochim. Acta A 2015, 148, 355-361. [CrossRef] [PubMed]

6. Zheng, X.; Zhang, Z.; Guo, Z.; Wang, Q. Flow-injection electrogenerated chemiluminescence detection of hydrazine based on its in-situ electrochemical modification at a pre-anodized platinum electrode. Analyst 2002, 127, 1375-1379. [CrossRef] [PubMed]

7. Karimi, M.A.; Mashhadizadeh, M.H.; Behjatmanesh-Ardakani, R.; Sahraie, N. A kinetic-potentiometric method for the simultaneous determination of hydrazine and acetylhydrazine. Asian J. Chem. 2009, 21, 3726-3740.

8. Guerra, S.V.; Kubota, L.T.; Xavier, C.R.; Nakagaki, S. Experimental optimization of selective hydrazine detection in flow injection analysis using a carbon paste electrode modified with copper porphyrin occluded into zeolite cavity. Anal. Sci. 1999, 15, 1231-1234. [CrossRef]

9. Jayasri, D.; Narayanan, S.S. Amperometric determination of hydrazine at manganese hexacyanoferrate modified graphite-wax composite electrode. J. Hazard Mater. 2007, 144, 348-354. [CrossRef] [PubMed]

10. Wang, G.; Gu, A.; Wang, W.; Wei, Y.; Wu, J.; Wang, G.; Zhang, X.; Fang, B. Copper oxide nanoarray based on the substrate of $\mathrm{Cu}$ applied for the chemical sensor of hydrazine detection. Electrochem. Commun. 2009, 11, 631-634. [CrossRef]

11. Wang, C.; Zhang, L.; Guo, Z.; Xu, J.; Wang, H.; Zhai, K.; Zhuo, X. A novel hydrazine electrochemical sensor based on the high specific surface area grapheme. Microchim. Acta 2010, 169, 1-6. [CrossRef]

12. Lee, K.K.; Loh, P.Y.; Sow, C.H.; Chin, W.S. CoOOH nanosheet electrodes: Simple fabrication for sensitive electrochemical sensing of hydrogen peroxide and hydrazine. Biosens. Bioelectron. 2013, 39, 255-260. [CrossRef] [PubMed] 
13. Yi, Q.; Yu, W. Nanoporous gold particles modified titanium electrode for hydrazine oxidation. J. Electroanal. Chem. 2009, 633, 159-164. [CrossRef]

14. Li, J.; Xie, H.; Chen, L. A sensitive hydrazine electrochemical sensor based on electrodeposition of gold nanoparticles on choline film modified glassy carbon electrode. Sens. Actuators. B: Chem. 2011, 153, $239-245$. [CrossRef]

15. Kim, S.K.; Jeong, Y.N.; Ahmed, M.S.; You, J.-M.; Choi, H.C.; Jeon, S. Electrocatalytic determination of hydrazine by a glassy carbon electrode modified with PEDOP/MWCNTs-Pd nanoparticles. Sens. Actuators $B$ 2011, 153, 246-251. [CrossRef]

16. Mehtaa, S.K.; Singha, K.; Umar, A.; Chaudharya, G.R.; Singha, S. Ultra-high sensitive hydrazine chemical sensor based on low-temperature grown ZnO nanoparticles. Electrochim. Acta 2012, 69, 128-133. [CrossRef]

17. Aziz, M.A.; Kawde, A.N. Gold nanoparticle-modified graphite pencil electrode for the high-sensitivity detection of hydrazine. Talanta 2013, 115, 214-221. [CrossRef] [PubMed]

18. Krittayavathananon, A.; Srimuk, P.; Luanwuthi, S.; Sawangphruk, M. Palladium nanoparticles decorated on reduced graphene oxide rotating disk electrodes toward ultrasensitive hydrazine detection: Effects of particle size and hydrodynamic diffusion. Anal. Chem. 2014, 86, 12272-12278. [CrossRef] [PubMed]

19. Yan, L.; Bo, X.; Zhu, D.; Guo, L. Well-dispersed Pt nanoparticles on polydopamine-coated ordered mesoporous carbons and their electrocatalytic application. Talanta 2014, 120, 304-311. [CrossRef] [PubMed]

20. Devasenathipathy, R.; Mani, V.; Chen, S.M. Highly selective amperometric sensor for the trace level detection of hydrazine at bismuth nanoparticles decorated graphene nanosheets modified electrode. Talanta 2014, 124, 43-51. [CrossRef] [PubMed]

21. Mohammadi, S.Z.; Beitollahi, H.; Asadi, E.B. Electrochemical determination of hydrazine using a $\mathrm{ZrO}_{2}$ nanoparticles-modified carbon paste electrode. Environ. Monit. Assess 2015, 187, 122. [CrossRef] [PubMed]

22. Ozoemena, K.I. Anodic oxidation and amperometric sensing of hydrazine at a glassy carbon electrode modified with cobalt (II) Phthalocyanine-cobalt (II) Tetraphenylporphyrin(CoPc-(CoTPP)4) supramolecular complex. Sensors 2006, 6, 874-891. [CrossRef]

23. Zhao, Z.; Sun, Y.; Li, P.; Sang, S.; Zhang, W.; Hu, J.; Lian, K. A sensitive hydrazine electrochemical sensor based on zinc oxide nano-wires. J. Electrochem. Soc. 2014, 161, B157-B162. [CrossRef]

24. You, T.; Niu, L.; Gui, J.Y.; Dong, S.; Wang, E. Detection of hydrazine, methylhydrazine and isoniazid by capillary electrophoresis with a 4-pyridyl hydroquinone self-assembled microdisk platinum electrode. J. Pharm. Biomed. Anal. 1999, 19, 231-237. [CrossRef]

25. Wu, M.; Ding, W.; Meng, J.; Ni, H.; Li, Y.; Ma, Q. Electrocatalytic behavior of hemoglobin oxidation of hydrazine based on $\mathrm{ZnO}$ nano-rods with carbon nanofiber modified electrode. Anal. Sci. 2015, 31, 1027-1033. [CrossRef] [PubMed]

26. Hu, J.; Zhao, Z.; Sun, Y.; Wang, Y.; Li, P.; Zhang, W.; Lian, K. Controllable synthesis of branched hierarchical $\mathrm{ZnO}$ nanorod arrays for highly sensitive hydrazine detection. Appl. Sur. Sci. 2016, 364, 434-441. [CrossRef]

27. Ye, W.C.; Wang, D.A.; Zhang, H.; Zhou, F.; Liu, W.M. Electrochemical growth of flowerlike gold nanoparticles on polydopamine modified ITO glass for SERS application. Electrochim. Acta 2010, 55, 2004-2009. [CrossRef]

28. Amiri, M.; Amali, E.; Nematollahzadeh, A. Poly-dopamine thin film for voltammetric sensing of atenolol. Sens. Actuators B: Chem. 2015, 216, 551-557. [CrossRef]

29. Fang, C.C.; Deng, Y.F.; Xie, Y.; Su, J.Y.; Chen, G.H. Improving the electrochemical performance of Si nanoparticle anode material by synergistic strategies of polydopamine and graphene oxide coatings. J. Phys. Chem. C 2015, 119, 1720-1728. [CrossRef]

30. Fu, L.; Lai, G.S.; Jia, B.H.; Yu, A.M. Preparation and electrocatalytic properties of polydopamine functionalized reduced graphene oxide-silver nanocomposites. Electrocatalysis-Us 2015, 6, 72-76. [CrossRef]

31. Zhang, N.; Ma, W.; He, P.G.; Long, Y.T. A polydopamine derivative monolayer on gold electrode for electrochemical catalysis of $\mathrm{H}_{2} \mathrm{O}_{2}$. J. Electroanal. Chem. 2015, 739, 197-201. [CrossRef]

32. Yang, J.; Niu, L.H.; Zhang, Z.J.; Zhao, J.; Chou, L.J. Electrochemical behavior of a polydopamine nanofilm. Anal. Lett. 2015, 48, 2031-2039. [CrossRef]

33. Lee, H.; Dellatore, S.M.; Miller, W.M.; Messersmith, P.B. Mussel-inspired surface chemistry for multifunctional coatings. Science 2007, 318, 426-430. [CrossRef] [PubMed]

34. Kim, B.K.; Son, S.; Lee, K.; Yang, H.; Kwak, J. Dopamine detection using the selective and spontaneous formation of electrocatalytic poly(dopamine) films on indium-tin oxide electrodes. Electroanalysis 2012, 24, 993-996. [CrossRef] 
35. Kim, B.K.; Lee, J.Y.; Park, J.H.; Kwak, J. Electrochemical detection of dopamine using a bare indium-tin oxide electrode and scan rate control. J. Electroanal. Chem. 2013, 708, 7-12. [CrossRef]

36. Kim, B.K.; Yang, S.Y.; Aziz, M.A.; Jo, K.; Sung, D.; Jon, S.; Woo, H.Y.; Yang, H. Electrochemical immunosensing chip using selective surface modification, capillary-driven microfluidic control, and signal amplification by redox cycling. Electroanalysis 2010, 22, 2235-2244. [CrossRef]

37. Park, S.; Hwang, S.; Takenaka, S.; Kim, K. Electrochemical sensing performances for uric acid detection on various amine adlayers used in immobilizing reduced graphene oxide. Electroanalysis 2015, 27, 1159-1165. [CrossRef]

38. Wei, Q.; Zhang, F.; Li, J.; Li, B.; Zhao, C. Oxidant-induced dopamine polymerization for multifunctional coatings. Polym. Chem. 2010, 1, 1430-1433. [CrossRef]

39. Armstrong, J.; Barlow, R.B. The ionization of phenolic amines, including apomorphine, dopamine and catecholamines and an assessment of zwitterion constants. Br. J. Pharmac. 1976, 57, 501-516. [CrossRef]

40. Malik, P.; Srivastava, M.; Verma, R.; Kumar, M.; Kumar, D.; Singh, J. Nanostructured $\mathrm{SnO}_{2}$ encapsulated guar-gum hybrid nanocomposites for electrocatalytic determination of hydrazine. Mater. Sci. Eng. C Mater. Biol. Appl. 2016, 58, 432-441. [CrossRef] [PubMed]

41. Ameen, S.; Akhtar, M.S.; Shin, H.S. Highly sensitive hydrazine chemical sensor fabricated by modified electrode of vertically aligned zinc oxide nanorods. Talanta 2012, 100, 377-383. [CrossRef] [PubMed]

42. Majidi, M.R.; Jouyban, A.; Asadpour-Zeynali, K. Electrocatalytic oxidation of hydrazine at overoxidized polypyrrole film modified glassy carbon electrode. Electrochim. Acta 2007, 52, 6248-6253. [CrossRef]

43. Ding, J.; Zhu, S.; Zhu, T.; Sun, W.; Li, Q.; Wei, G.; Su, Z. Hydrothermal synthesis of zinc oxide-reduced graphene oxide nanocomposites for an electrochemical hydrazine sensor. RSC Adv. 2015, 5, 22935-22942. [CrossRef]

44. Andre, R.S.; Pavinatto, A.; Mercante, L.A.; Paris, E.C.; Mattoso, L.H.C.; Correa, D.S. Improving the electrochemical properties of polyamide $6 /$ polyaniline electrospun nanofibers by surface modification with ZnO nanoparticles. RSC Adv. 2015, 5, 73875-73881. [CrossRef]

45. Li, Y.; Li, J.; Xia, X.H.; Liu, S.Q. Direct electrochemistry of cytochrome c immobilized on a novel macroporous gold film coated with a self-assembled 11-mercaptoundecanoic acid monolayer. Talanta 2010, 82, 1164-1169. [CrossRef] [PubMed]

46. Zhang, X.; Ma, W.; Nan, H.; Wang, G. Ultrathin zinc oxide nanofilm on zinc substrate for high performance electrochemical sensors. Electrochim. Acta 2014, 144, 186-193. [CrossRef]

47. Zhou, B.; Yang, J.; Jiang, X. Porous Mn2O3 nanorods synthesized from thermal decomposition of coordination polymer and used in hydrazine electrochemical sensing. Mater. Lett. 2015, 159, 362-365. [CrossRef]

48. Zhang, O.; Yu, H.-M.; Lu, L.-M.; Wen, Y.-P.; Duan, X.-M.; Xu, J.-K. Poly(thiophene-3-acetic acid)-palladium nanoparticle composite modified electrodes for supersensitive determination of hydrazine. Chin. J. Polym. Sci. 2013, 31, 419-426. [CrossRef]

49. Tolstopjatova, E.G.; Kondratiev, V.V.; Eliseeva, S.N. Multi-layer PEDOT:PSS/Pd composite electrodes for hydrazine oxidation. J. Solid State Electrochem. 2015, 19, 2951-2959. [CrossRef]

50. Rastogi, P.K.; Ganesan, V.; Krishnamoorthi, S. Palladium nanoparticles decorated gaur gum based hybrid material for electrocatalytic hydrazine determination. Electrochim. Acta 2014, 125, 593-600. [CrossRef]

51. Kocak, S.; Aslısen, B. Hydrazine oxidation at gold nanoparticles and poly(bromocresol purple) carbon nanotube modified glassy carbon electrode. Sens. Actuators B: Chem. 2014, 196, 610-618. [CrossRef]

52. Kazemi, S.H.; Hosseinzadeh, B.; Zakavi, S. Electrochemical fabrication of conducting polymer of Ni-porphyrin as nano-structured electrocatalyst for hydrazine oxidation. Sens. Actuators B: Chem. 2015, 210, 343-348. [CrossRef]

53. Foster, C.W.; Pillay, J.; Metters, J.P.; Banks, C.E. Cobalt phthalocyanine modified electrodes utilised in electroanalysis: Nano-structured modified electrodes vs. bulk modified screen-printed electrodes. Sensors 2014, 14, 21905-21922. [CrossRef] [PubMed]

(C) 2016 by the authors; licensee MDPI, Basel, Switzerland. This article is an open access article distributed under the terms and conditions of the Creative Commons Attribution (CC-BY) license (http://creativecommons.org/licenses/by/4.0/). 